\title{
BMJ Open 'It's on your conscience all the time': a systematic review of qualitative studies examining views on obesity among young people aged $12-18$ years in the UK
}

\author{
Rebecca W Rees, Jenny Caird, Kelly Dickson, Carol Vigurs, James Thomas
}

To cite: Rees RW, Caird J, Dickson $\mathrm{K}$, et al. 'It's on your conscience all the time': a systematic review of qualitative studies examining views on obesity among young people aged 12-18 years in the UK. BMJ Open 2014;4:e004404. doi:10.1136/ bmjopen-2013-004404

- Additional material is available. To view please visit the journal (http://dx.doi.org/ 10.1136/bmjopen-2013004404).

Received 4 November 2013 Revised 31 January 2014 Accepted 10 February 2014

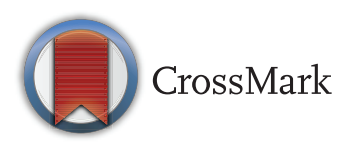

EPPI-Centre, Social Science Research Unit, Department of Children and Health, Institute of Education, University of London, London, UK

Correspondence to Rebecca W Rees; r.rees@ioe.ac.uk

\section{ABSTRACT}

Objective: To explore the perspectives of young people in the UK on obesity, body size, shape and weight.

Design: Systematic review of qualitative studies using thematic synthesis.

Data sources: Sensitive searches of 18 electronic databases from 1997 to February 2010 supplemented by grey literature searches.

Study selection: Studies produced since 1997 using qualitative methods to collect perspectives of people aged 12-18 years in the UK, reporting methods for data collection or analysis. Studies of people with eating disorders and those rated low in reliability and usefulness were excluded.

Results: Searches identified 30 studies involving over 1400 young people from a range of contexts. Young people of all sizes placed considerable emphasis on personal responsibility, and on the social, rather than health implications of being overweight. Young people with experience of obesity described severe, unrelenting, size-related abuse and isolation. Regardless of their own size, young people were judgemental of individuals who were overweight, but those with experience of obesity described an environment that contained multiple barriers to weight loss. Only one study asked young people directly what might support them to have a healthy body size. Study findings were configured under three main themes, labelled with quotes from included studies: general perceptions of size and society's responses ('It's on your conscience all the time'); the experiences of young people who were overweight ('If I had the choice I wouldn't be this size') and these larger young people's experiences of trying to loose weight and suggestions for action ('Make sure, even when it's hard, you've got people there').

Conclusions: The perspectives of young people in the UK, when synthesised across the spectrum of body sizes, paint a picture of a stigmatising and abusive social world. Research and policy need to engage young people actively so as to address the social implications of obesity.

\section{Strengths and limitations of this study}

- Together, the synthesised studies included a total of over a thousand young people with experience of a range of body sizes.

- Comprehensive searches sought out less easily identifiable literature that increased the richness of data for analysis.

- The review identified only a small body of studies that enabled young people to help identify priorities for study and analysis.

\section{BACKGROUND}

Obesity in young people in the UK continues to be a public health issue. A recent England-wide survey found that over $23 \%$ of boys and $16 \%$ of girls aged 11-15 would be grouped in this category. ${ }^{1}$ Young people who are overweight can experience physical illhealth due to obesity while they are still young $^{23}$ and have an increased risk of being overweight as an adult. ${ }^{4}$ Studies have found low levels of mental health in young people classified as obese. ${ }^{5}$

The influences on body weight are complex and multilevelled. Highly complicated 'system maps' have been developed to try to describe the many links between body weight and biological and genetic factors, individual behaviour and influences from individuals' social and physical surroundings. ${ }^{6}$ Nonetheless, press coverage often emphasises individual choices over structural factors that might influence weight gain. ${ }^{7} 8$ In contrast, weight gain in the population has been characterised in the field of public health as, 'the inevitable-and largely involuntary-consequence of exposure to a modern lifestyle ${ }^{9}$, or due to the 'obesogenic environment'. ${ }^{10}$ It is also recognised that, once a certain weight is gained, multiple factors act to make that 
weight extremely difficult to lose, and even likely to increase. $^{11}$

In terms of social values, despite its increasing prevalence, obesity still transgresses social norms. To be very overweight is seen as morally reprehensible. ${ }^{12}{ }^{13}$ Judgements in the general population about obesity are imbued with ideas about personal responsibility and stereotyping is common, with obesity linked with socially undesirable behaviours and other attributes, such as weakness of will, laziness and greed. ${ }^{14}{ }^{15}$ Such attitudes appear to be mirrored in people's behaviours and experiences; studies of adults who are very overweight show that they experience both stigma and discrimination and that this impacts negatively on their wellbeing. ${ }^{16-18}$

Research evidence to help us decide how to prevent or deal with obesity in young people is limited. ${ }^{19} 20$ Intervention research regularly fails to consider what young people themselves think, ${ }^{21}$ and yet young people are likely to have insights into factors that influence their own weight and that of their peers, and ideas about how they can be supported to keep their own weight within a healthy range. Research that explores these insights can inform initiatives that aim for positive outcomes. ${ }^{22} 23$

The techniques available for systematic reviews of research, perhaps better known for the aggregation of intervention effect sizes, also include those for meshing together, or configuring, study findings. ${ }^{24}$ Configuration in systematic reviews can help make sense of multiple accounts from varied perspectives and so build theory about lived experience. ${ }^{25} 26$ The authors know of only five previous systematic reviews that include views on body size. A companion review to this study explored children's views (aged 4-11). ${ }^{27}$ The others all explore the views of adults, ${ }^{28-31}$ with the first of these also including the perspectives of young people diagnosed as obese. The systematic review presented here examines recent research findings from the UK where young people aged from 12 to 18 years provide views about their own body sizes or about the body sizes of others. It aims to help inform the development of practice and policy-based initiatives and the commissioning of further research in ways that put the perspectives of young people at the fore-front.

\section{A note on language}

Descriptive terms for body size are extremely value laden. We have tried to restrict our use of terms that could potentially further stigmatise individuals or cause offence. We have avoided unqualified use of possibly pejorative terms unless young people or others are quoted as using them to describe themselves. It is also difficult to report body size variation in the literature with precision, since the body sizes of participating young people are often not explicitly specified by study authors, or identified by young people themselves. When authors have indicated a distinction, we have used the phrase 'healthy weight/size' to contrast young people who are not overweight with those who would be classified as overweight. We have used 'large', 'larger', or 'overweight' interchangeably to indicate that young people have a larger body size when this information is available in study reports. We have also used the phrases 'very overweight/ large' to indicate that a young person is identified as having been diagnosed as clinically obese, or as having a body mass index (BMI) in excess of 30 .

\section{METHODS}

We searched 18 electronic databases from the fields of health, public health, education, social science and social care in February/March 2010, taking care to include sources rich in the UK-based journal and report literature. Controlled term and free-text searches were used that combined sets of terms for young people, body size, views research and geographical location. We also searched six key journals and 54 websites by hand, used Internet search engines, scanned reference lists, looked for papers that had cited key studies, and contacted key informants for relevant research (see online supplementary file 1). We managed review data using the specialised online review software EPPI-Reviewer. ${ }^{32}$

\section{Study selection}

We included studies that reported views about obesity, body size, shape or weight, sought from young people in the UK aged 12-18 years. We defined views as attitudes, opinions, beliefs, feelings, understandings or experiences, and excluded studies that measured only health or weight status, behaviour or factual knowledge. Studies needed to have used qualitative data collection methods (eg, in-depth or semistructured interviews and/or focus groups) and, as a minimum, to have described one of two key aspects of a study's methods (data collection or analysis). We sought studies published in English since the start of 1997 (to cover a period of heightened interest in the topic of obesity). We excluded studies solely of young people with an eating disorder diagnosis, on the basis that this group may be considered exceptional in terms of their requirements for achieving or maintaining a healthy weight. This last criterion was the only one not set out in the review's protocol (for access to this see data sharing statement). These inclusion criteria were piloted by the first four authors of this study so as to develop shared understandings of the criteria. A sample of early screening decisions was double-checked by the first author. Screening was thereafter carried out individually.

\section{Describing and appraising studies}

We described the final set of included studies using a standardised classification system, ${ }^{33}$ supplemented using frameworks from previous reviews of the views of children and young people. ${ }^{25}$ The quality of included 
studies was appraised using criteria modified from a set developed for examining the findings of evaluations of intervention processes (box 1). ${ }^{34}{ }^{35}$ The studies were each allocated a 'weight of evidence' with two dimensions. First, we rated the reliability of the findings (using criteria 1-4). Second, we rated the findings' usefulness (based on the richness and complexity of analysis, and the privileging of perspectives, eg, methods encouraging young people to prioritise issues for discussion-using criteria 5 and 6). Two reviewers worked independently on each study, before reaching consensus. We excluded studies from the synthesis if they were rated low on both dimensions.

\section{Analysis}

Four reviewers worked on the analysis. We used thematic synthesis to examine each line of each study's findings and create codes that described meaning and content. This approach to synthesis is particularly suitable for systematic reviews, because the discipline of line-by-line coding requires that reviewers consider carefully each aspect of every study; and whether or not a finding from one study really does 'translate' into another. ${ }^{36}$ It also enables findings and new conceptualisations to emerge inductively from the included studies, and so is a good fit with one of the principles of our review which aimed to highlight young people's own perspectives. Findings were sought throughout the report, not just from results sections. We looked first at studies with views from young people described as having experience of being overweight, and then moved on to the remainder. We looked for similarities and differences between codes as the code set grew, and attempted to identify a smaller set of themes that captured the most recurrent and most emphasised ideas across the full range of studies' findings, while also looking for contradictory ideas. This smaller set of ideas was developed in the light of the review's questions, the themes identified in our earlier review of children's views, ${ }^{27}$ and authors' descriptions of body size status (experience of overweight vs otherwise). The lead author then wrote a narrative to describe the themes, with direct quotes from the included studies used both within the narrative and as theme headings so as to illustrate young people's own representations of their views. We also consulted a group of young people (PEAR), convened by the National Children's Bureau to enable young people's views and opinions to influence public health research. ${ }^{37}$ We worked with the group for $1.5 \mathrm{~h}$ within a longer group residential. The group was presented with illustrations of the synthesis themes and asked whether this seemed believable and whether anything might be missing, as well as for ideas about how to present findings. The processes for consulting members of the PEAR group were approved by a Faculty Research Ethics Committee at the Institute of Education. Further detail on this group is available in the technical report (see Data sharing statement).

\section{RESULTS}

The state of the literature

We found and screened 28267 citations and identified 30 studies for the review's synthesis (see online supplementary file 2 presents the flow of studies through the review).

The 30 studies varied considerably in terms of their stated aims and data collection methods. Table 1 describes each study briefly and specifies the code that is used to reference the study in this paper (w1-30). Thirteen studies focused directly on body size, shape or weight. Five of these focused on the views of young people who were or who had been overweight about their recent experience of an intervention for losing weight, ${ }^{\text {w4 }}{ }^{\text {w13-14 }}$ w21 or encouraging physical activity. ${ }^{\mathrm{w}}$ The other eight asked young people to describe their own and others' experiences of being a certain body size, or for more general views about body size or image. $^{\mathrm{w} 7}$ w9 w11-12 w15 w17 w28-29 The remaining 17 studies focused on young people's overall health needs, ${ }^{\text {w16 w22-24 }}$ food, ${ }^{\text {w19 }}{ }^{\text {w30 }}$ smoking, ${ }^{\text {w10 }}{ }^{\text {w18 }}$ cancer, ${ }^{\text {w26 }}$ clothes and identity, ${ }^{\mathrm{w} 27}$ physical education (PE), ${ }^{\mathrm{w} 2-\mathrm{w} 3}$ w6 w8 w25 and physical activity. ${ }^{\text {w1 }}{ }^{20}$ Most, but not all of the findings from young people with experience of being overweight were identified from nine studies. ${ }^{\text {w4-w5 }}$ w9 w12-w14 w21 w28-w29 It was often not possible, from these and other studies, to identify the extent to which participating young people were overweight (eg, classifiable as obese, as opposed to overweight).

In terms of quality, only three studies ${ }^{\mathrm{w} 4} \mathrm{w12}^{\mathrm{w} 28}$ were judged to have highly reliable findings (see online supplementary file 3). Seven studies were judged to be highly useful. ${ }^{\mathrm{w} 4-\mathrm{w} 5}$ w9 w12-w14 w28 Six studies were excluded from the synthesis on quality grounds. ${ }^{67-72}$ (For an indication of the contribution of each included study see online supplementary file 4 .)

\section{Young people's views}

Analysis of the findings of each study resulted in three main themes, each with further subthemes (table 2): (1) general perceptions about different body sizes and society's responses to them-which were often couched in moral terms ('It's on your conscience all the time'); (2) overweight young people's experiences that they linked to their size ('If I had the choice, I wouldn't be this size') and (3) overweight young people's experiences of trying to lose and maintain weight and their suggestions for action ('Make sure, even when it's hard, you've got people there'). The PEAR group considered these themes to be believable but members were concerned by the severity of accounts that they read. They suggested that when writing-up we should try to avoid further upset. In response, we attempted to avoid language that labelled young people, and included in the synthesis cases illustrating constructively resistant or positive attitudes. The remaining part of this section details the findings of the synthesis, with each of the above main themes addressed in turn. 


\section{Box 1 Criteria used to appraise study quality*}

Criterion (with guidance for reviewers)

1. Were steps taken to increase rigour in the sampling?

Consider whether:

- The sampling strategy was appropriate to the questions posed in the study (eg, was the strategy well reasoned and justified?);

- Attempts were made to obtain a diverse sample of the population in question (think about who might have been excluded; who may have had a different perspective to offer);

- Characteristics of the sample critical to the understanding of the study context and findings were presented (ie, do we know who the participants were in terms of, eg, basic sociodemographics, characteristics relevant to the context of the study, etc).

2. Were steps taken to increase rigour in the data collected?

Consider whether:

- Data collection tools were piloted/(and if quantitative) validated;

- (If qualitative) data collection was comprehensive, flexible and/or sensitive enough to provide a complete and/or vivid and rich description of people's perspectives and experiences (eg, did the researchers spend sufficient time at the site/with participants? Did they keep 'following up'? Was more than one method of data collection used?);

- Steps were taken to ensure that all participants were able and willing to contribute (eg, processes for consent, language barriers, power relations between adults and children/young people).

3. Were steps taken to increase rigour in the analysis of the data?

Consider whether:

- Data analysis methods were systematic (eg, was a method described/can a method be discerned?);

- Diversity in perspective was explored;

- (If qualitative) the analysis was balanced in the extent to which it was guided by preconceptions or by the data);

- The analysis sought to rule out alternative explanations for findings (in qualitative research this could be carried out by, eg, searching for negative cases/exceptions, feeding back preliminary results to participants, asking a colleague to review the data, or reflexivity; in quantitative research this may be carried out by, eg, significance testing).

4. Were the findings of the study grounded in/ supported by the data?

Consider whether:

- Enough data are presented to show how the authors arrived at their findings;

- The data presented fit the interpretation/support claims about patterns in data;

- The data presented illuminate/illustrate the findings;

- (For qualitative studies) quotes are numbered or otherwise identified and the reader can see that they don't just come from one or two people.

5. Please rate the findings of the study in terms of their breadth and depth.

Consider whether:

(NB: it may be helpful to consider 'breadth' as the extent of description and 'depth' as the extent to which data has been transformed/analysed);

- A range of issues are covered;

- The perspectives of participants are fully explored in terms of breadth (contrast of two or more perspectives) and depth (insight into a single perspective);

- Richness and complexity has been portrayed (eg, variation explained, meanings illuminated);

- There has been theoretical/conceptual development.

6. To what extent does the study privilege the perspectives and experiences of young people?

Consider:

- Whether there was a balance between open-ended and fixed response options;

- Whether children were involved in designing the research;

- Whether there was a balance between the use of an a priori coding framework and induction in the analysis;

- The position of the researchers (did they consider it important to listen to the perspectives of children?);

- Whether steps were taken to assure confidentiality and put young people at ease.

7. Overall, what weight would you assign to this study in terms of the reliability/trustworthiness of its findings?

Guidance: Think (mainly) about the answers you have given to questions 1 to 4 above.

8. What weight would you assign to this study in terms of the usefulness of its findings for this review?

- Guidance: Think (mainly) about the answers you have given to questions 5 and 6 above and consider:

- The match between the study aims and findings and the aims and purpose of the synthesis;

- Its conceptual depth/explanatory power.

*The following responses were available for these questions: (1-3) Yes, a fairly thorough attempt was made; Yes, several steps were taken; Yes, a few steps were taken; No, not at all/Not stated/Can't tell. (4) Good grounding/support; fair grounding/support; limited grounding/ support. (5) Limited breadth or depth; good/fair breadth but very little depth; good/fair depth but very little breadth; good/fair breadth and depth. 6. Not at all; a little; somewhat; a lot. 
Table 1 Details of included studies: aims and sample characteristics $(\mathrm{N}=30)$

Study

\section{(reference no) Aims}

Billings et $a{ }^{\mathrm{w1} 38} \quad$ To explore factors which motivate and create barriers to engagement in regular physical activity for 11-12 and 14-15-year-old girls

Bramham w2 39

To explore boys' perceptions and experiences of school-based PE and involvement in extracurricular and out-of-school physical activities

Cockburn and To explore the cultural and subcultural aspects

Clarke w3 40 of teenage girls' and young women's lives which influence their involvement in sport and PE

Curtis w4 41 To explore the experiences of young people with obesity within the secondary schoo environment in relation to areas of concern prioritised by the HSP

Daley et al. w5 $42 \quad$ A qualitative study nested within a randomised controlled trial explored obese adolescents' experiences of participation in an exercise therapy intervention

Flintoff and

Scraton w6 43

To explore young women's perspectives of and attitudes towards involvement in physical activity and PE. Explores the nature, purposes and experiences of involvement, both in and out of school and interface between identities, structures and cultural settings. Located within developing feminist theoretical debates

Frost w7 44 A theoretical, feminist, sociological enquiry examining the direct perception of young women about how they, and their contemporaries, experience their bodies

Gorely et al. w8 45 To develop the concept of gender-relevant physical education combining the work of Pierre Bourdieu and his notion of the habitus and feminist philosopher Iris Marion's analysis of feminine motility by drawing on data generated from a study of young people's articulation of the relationships between muscularity, physicality and gender

Griffiths and To examine the relationship between obesity

Page w9 46
Sample size

91

6

Weight status muscular) (mainly) obese
Data collection and analysis methods

\section{Group interviews}

Content analysis

Mesomorphic (ie, compact and

Individual and group interviews Data analysis method not reported

Individual interviews Reflexive interpretation and biographical analysis

Not stated (participants recruited from community-based obesity intervention programme)

Classified as obese or morbidly

Individual and group interviews Thematic analysis

Individual interviews

Thematic analysis

Mesomorphic (mainly)

Individual interviews

Thematic analysis

Group interviews before and after art class, plus questionnaire

Data analysis method not stated

Group and individual interviews

Data analysis method not stated

Sequence of two to three individua interviews

Interpretative phenomenological analysis 


\begin{tabular}{|c|c|c|c|c|}
\hline $\begin{array}{l}\text { Study } \\
\text { (reference no) }\end{array}$ & Aims & Sample size & Weight status & Data collection and analysis methods \\
\hline $\begin{array}{l}\text { Grogan } \\
\text { et al w10 } 47\end{array}$ & $\begin{array}{l}\text { To investigate how young men and women } \\
\text { smokers and non-smokers talk about the } \\
\text { impact of smoking on appearance, with the aim } \\
\text { of using these accounts to inform antismoking } \\
\text { campaigns targeted at young people }\end{array}$ & 47 & Not stated & $\begin{array}{l}\text { Group interviews } \\
\text { Thematic analysis }\end{array}$ \\
\hline $\begin{array}{l}\text { Grogan and } \\
\text { Richards w11 } 48\end{array}$ & $\begin{array}{l}\text { To understand how men and boys construct } \\
\text { body image including their views on body } \\
\text { dissatisfaction, body shape ideals and } \\
\text { behavioural concomitants of body image }\end{array}$ & 12 & $\begin{array}{l}\text { none were notably overweight or } \\
\text { underweight as judged by the } \\
\text { researchers }\end{array}$ & $\begin{array}{l}\text { Group interviews } \\
\text { Thematic analysis }\end{array}$ \\
\hline $\begin{array}{l}\text { Health } \\
\text { Experience } \\
\text { Research } \\
\text { Groupw12 } 49 \\
\text { (a-w: see note at } \\
\text { table foot) }\end{array}$ & $\begin{array}{l}\text { To examine a range of peoples' perspectives in } \\
\text { terms of what someone might expect to } \\
\text { experience when diagnosed with a particular } \\
\text { condition or illness. All the young people and } \\
\text { parents interviewed had been affected by } \\
\text { weight issues. The research was carried out } \\
\text { with the aim of populating a website } \\
\text { 'youthhealthtalk.org', so as to help people } \\
\text { 'share in young people's experiences of health } \\
\text { and illness' }\end{array}$ & 24 & $\begin{array}{l}\text { Some of the young people had } \\
\text { been told they were overweight or } \\
\text { were in the medical category } \\
\text { 'obese' }\end{array}$ & $\begin{array}{l}\text { Individual interviews, sometimes with friend } \\
\text { present } \\
\text { Thematic analysis }\end{array}$ \\
\hline Hester et al w13 50 & $\begin{array}{l}\text { To uncover in-depth qualitative accounts of } \\
\text { intervention impact from obese young people } \\
\text { during a period of lifestyle change after } \\
\text { attending a residential weight-loss camp }\end{array}$ & 5 & Classified as obese & $\begin{array}{l}\text { Researcher participation in intervention prior } \\
\text { to individual interviews } \\
\text { Thematic analysis }\end{array}$ \\
\hline Holt et al w14 51 & $\begin{array}{l}\text { To explore children's perceptions of attending a } \\
\text { residential paediatric weight-loss camp }\end{array}$ & 15 & Classified as obese & $\begin{array}{l}\text { Individual interviews } \\
\text { Thematic analysis }\end{array}$ \\
\hline $\begin{array}{l}\text { Krayer } \\
\text { et al. w15 } 52\end{array}$ & $\begin{array}{l}\text { To describe the nature of social comparison } \\
\text { processes mentioned spontaneously by boys } \\
\text { and girls with a particular focus on } \\
\text { enhancement comparisons }\end{array}$ & 20 & Not stated & $\begin{array}{l}\text { Sequence of two individual interviews } \\
\text { Grounded theory approach }\end{array}$ \\
\hline $\begin{array}{l}\text { Kurtz and } \\
\text { Thornes w16 } 53\end{array}$ & $\begin{array}{l}\text { To gather children's views about their health } \\
\text { needs to inform policy and the strategic } \\
\text { development of services for school-age } \\
\text { children in England }\end{array}$ & 43 & Not stated & $\begin{array}{l}\text { Group interviews } \\
\text { Data analysis method not stated }\end{array}$ \\
\hline $\begin{array}{l}\text { Lloyd and Dittmar } \\
\text { w17 } 54\end{array}$ & $\begin{array}{l}\text { To broaden and deepen understanding of } \\
\text { 'normal' adolescent boys' and girls' body image } \\
\text { concerns, in order to provide an appropriate } \\
\text { basis for interventions aimed at promoting } \\
\text { healthier diet and lifestyle }\end{array}$ & 56 & Not stated & $\begin{array}{l}\text { Individual and group interviews } \\
\text { Thematic analysis }\end{array}$ \\
\hline Lucas et $a /^{w 1854 a}$ & $\begin{array}{l}\text { To explore adolescents' use of cigarettes to } \\
\text { moderate negative emotions }\end{array}$ & $\begin{array}{l}32 \text { groups with } \\
2-6 \text { girls in each } \\
\text { group }\end{array}$ & Not stated & $\begin{array}{l}\text { Group interview with a video presentation to } \\
\text { encourage discussion } \\
\text { Thematic analysis }\end{array}$ \\
\hline
\end{tabular}




\begin{tabular}{|c|c|c|c|c|}
\hline $\begin{array}{l}\text { Ludvigsen and } \\
\text { Sharma w19 } 55\end{array}$ & $\begin{array}{l}\text { To examine the influences on children and } \\
\text { young people in their food choices during the } \\
\text { school day }\end{array}$ & 54 & Not stated. & $\begin{array}{l}\text { Participant observation and questionnaires } \\
\text { followed by group interviews using } \\
\text { photographs as prompts } \\
\text { Data analysis method not stated }\end{array}$ \\
\hline $\begin{array}{l}\text { Mulvihill } \\
\text { et al. }{ }^{\text {w20 }} 56\end{array}$ & $\begin{array}{l}\text { To provide data on the reported drivers and } \\
\text { barriers to physical activity among young } \\
\text { people aged 5-15 years }\end{array}$ & 103 & Not stated & $\begin{array}{l}\text { Group interviews } \\
\text { Data analysis method not stated }\end{array}$ \\
\hline $\begin{array}{l}\text { Percy-Smith } \\
\text { w22 } 58\end{array}$ & $\begin{array}{l}\text { To explore young people's understandings and } \\
\text { experiences of health as experienced in their } \\
\text { everyday lives and according to their own } \\
\text { terms of reference rather than in response to } \\
\text { policy priorities }\end{array}$ & 62 & Not stated & $\begin{array}{l}\text { Participative action research using: young } \\
\text { people considering relevant research } \\
\text { conducted by their peers, followed by } \\
\text { interactions between young people and } \\
\text { health professionals, group art work and } \\
\text { plenary discussion } \\
\text { Thematic analysis }\end{array}$ \\
\hline $\begin{array}{l}\text { Shucksmith and } \\
\text { Hendry w24 } 60\end{array}$ & $\begin{array}{l}\text { To examine young people's views about diet, } \\
\text { weight, their appearance and the impact of } \\
\text { fashion norms }\end{array}$ & $\begin{array}{l}50 \text { group } \\
\text { interviews, } 44 \\
\text { individual } \\
\text { interviews }\end{array}$ & Not stated & $\begin{array}{l}\text { Group interviews } \\
\text { Thematic analysis }\end{array}$ \\
\hline $\begin{array}{l}\text { Velija and } \\
\text { Kumarw25 } 61\end{array}$ & $\begin{array}{l}\text { To explore, through focus group interviews with } \\
\text { year } 10 \text { girls, how girls' experiences of PE and } \\
\text { GCSE PE are gendered }\end{array}$ & 16 & Not stated & $\begin{array}{l}\text { Group interviews } \\
\text { Thematic analysis }\end{array}$ \\
\hline $\begin{array}{l}\text { Wallace } \\
\text { et al. }{ }^{26} 62\end{array}$ & $\begin{array}{l}\text { To explore adolescents' experience of the } \\
\text { impact of having cancer, including the burden } \\
\text { of illness, treatments and resultant appearance } \\
\text { changes }\end{array}$ & 8 & Not stated & $\begin{array}{l}\text { Individual interviews } \\
\text { Interpretative phenomenological analysis }\end{array}$ \\
\hline Willett w27 63 & $\begin{array}{l}\text { To provide empirical evidence which will look } \\
\text { past the structure-agency dichotomy to see } \\
\text { how human agency and social structure act } \\
\text { through each other to influence pre-teen and } \\
\text { teen girls' consumption of fashion and digital } \\
\text { media }\end{array}$ & 26 & Not stated & $\begin{array}{l}\text { Art work and individual interviews } \\
\text { Thematic analysis }\end{array}$ \\
\hline
\end{tabular}




\begin{tabular}{|c|c|c|c|c|}
\hline $\begin{array}{l}\text { Study } \\
\text { (reference no) }\end{array}$ & Aims & Sample size & Weight status & Data collection and analysis methods \\
\hline Wills et al. w28 64 & $\begin{array}{l}\text { To explore the embodied perceptions of obese, } \\
\text { overweight and 'normal' weight young } \\
\text { teenagers (from socioeconomically } \\
\text { disadvantaged families living in Eastern } \\
\text { Scotland), within the sociocultural contexts in } \\
\text { which these young teenagers live their } \\
\text { everyday lives }\end{array}$ & 36 & $\begin{array}{l}\text { Classified as overweight or obese } \\
(\mathrm{N}=18) \text {, 'normal' weight }(\mathrm{N}=18)\end{array}$ & $\begin{array}{l}\text { Individual interviews } \\
\text { Thematic analysis }\end{array}$ \\
\hline Wills et al. w29 65 & $\begin{array}{l}\text { To examine the dietary practices and health } \\
\text { and weight conceptualisations of BMI-defined } \\
\text { obese/overweight and non-obese/overweight } \\
\text { young teenagers from middle-class families; to } \\
\text { situate these observations within the 'habitus' } \\
\text { of the family by exploring these issues from the } \\
\text { perspectives of their parents; and to compare } \\
\text { these data to the data already collected in an } \\
\text { earlier study involving young working-class } \\
\text { teenagers }\end{array}$ & 36 & $\begin{array}{l}\text { Classified as overweight or obese } \\
(\mathrm{N}=18) \text {, 'normal' weight }(\mathrm{N}=18)\end{array}$ & $\begin{array}{l}\text { Individual interviews } \\
\text { Thematic analysis }\end{array}$ \\
\hline Wills w30 66 & $\begin{array}{l}\text { To examine how the new social contexts } \\
\text { experienced by young people after leaving } \\
\text { school are related to everyday food practices } \\
\text { and eating habits }\end{array}$ & 31 & Not stated & $\begin{array}{l}\text { Food diaries and individual interviews } \\
\text { Thematic analysis }\end{array}$ \\
\hline
\end{tabular}


Table 2 Quotations from study participants to illustrate each theme

Themes Illustrative quotes from participants (also see quotes in the text) (Study reference no.)

It's on your conscience all the time

It's down to me

It's like a girl thing?

If you're fat, then they don't like you

People that are right big have right dirty houses

Being fat is really a bad thing (w23, p.156)

If I had the choice, I wouldn't

Not wanting to stick out $^{\text {w12b }}$

Day after day, you're that terrified

Vicious circles
I mean if you're the one that wants to lose weight, then you can't say 'Right, mum, can you lose weight for me? '... you're the one who has to go oot for exercise and cut doon on your foods and that eh? That's... what I ken, its doon tae me. (Nick, male, 13 years, ethnicity unspecified, very overweight) (w28, p.400)

I would love to say it's all to do with genetics and I have nothing to do with it, but I know that what I do isn't particularly healthy and therefore it's due to me as well... I think it's for me it's just the fact that l'm stubborn and lazy and that I like eating my food. (Holly, female, 18 years, white, very overweight) ${ }^{\mathrm{w} 12 \mathrm{~m}}$

Tobias: ...I'm a couple of inches shorter than all my friends as well and I feel pressure. Tom: If you've got friends who are like quite big in build you want to be the same as them. Although you might not be able to do anything about it, it's on your conscience all the time. You want to be that sort of size. (Tobias and Tom, male, 16-17 years, ethnicity unspecified, healthy weight) (w11, p.229)

...they (boys) think that if you look good then you're okay but if you're fat... then they don't like you. (female, 11-14 years, ethnicity and body size unspecified) (w18, p.24)

Like when you start thinking ahead, like what are you going to be like, people just sit at home eating pizza all time, I wouldn't like to be one those boring people. I want to be a person that can go out, go on holiday, go to work, have lots of friends, get out of the house... you watch a lot of programmes all people that are right big have right dirty houses. (male, 14 years, white, very overweight, BMI 31.3) (w5, p.814)

If you've got someone in your family who's quite fat, you see how they are and you think to yourself, I don't want to be like that. ...It's a bit of a turnoff if you're fat, so you try not to get like that. (Tony, male, 16-17 years, white, body size unspecified) (w11, p.226)

I think it's all down to like your mental, your mental picture of yourself really ... it's when you're like, 'Oh I feel so bad and ugly today.' That, that's when you become really bad, and so size isn't the thing, it's more... the way you act, if you act like all closed and in a corner and not socialising, then I mean attractive is someone who is the life and soul of the party, dancing in the middle, having a good laugh.' (Huw, male, 17 years, white, overweight) ${ }^{\text {w12j }}$

be this size

But the places where I go most of the clientele are like a lot older than me... And that's weird to think that, you know, you'll be, you're wearing the same clothes as like your 50-year-old neighbour or whatever... And it isn't nice... you are always thinking about it, especially in public... if I had the choice I wouldn't be this size. (Rachel, female, 17 years, white, overweight) ${ }^{\text {w12d }}$ ...it makes you feel really bad 'cos if they're going, 'Oh I'm too fat, ' how's that supposed to ... make you feel 'cos when you're like twice the size of 'em? (Huw, 17 years, white, overweight) ${ }^{\mathrm{w} 12 \mathrm{~b}}$

it wasn't just a group thing, it was walk down the corridor, and I actually counted this one day. how many people said something to me, just walking about a hundred yards twenty-three people I think, and you know every day in between every lesson and going, you know, it gets a lot. (Becca, female, 17 years, white, overweight) ${ }^{\text {w12c }}$

Day after day, walking in ... you're that terrified that you don't want to go school, this is what my point of view were like... 3 years I tried not going to school because I used to get bullied and my mum got took to court. (Eve, female, age and ethnicity unspecified, very overweight) (w4, p.414) I've put on the weight and I still want to do it [participate in PE classes] but it's the glances, it's the sniggers, it's the laughs, stupid things that people were saying, 'look at her running along, she can barely keep-up.' (Sam, female, 15 years, overweight, BMI 38.0) (w9, p.41)

I don't like having to walk into places where I don't know anyone or walking past a group of people; I don't like walking past because of things they might say and they are less likely to say if l've got Diane [sister] with me. (Jane, 17 years, ethnicity unspecified, overweight, BMI 46.7) (w4, p.42)

I was just getting bullied all the time and nobody wanted to be with me. I was always on my own in my bedroom doing my own thing.... [For the first 6 weeks of a weight-loss programme] I just sat in a corner, didn't talk to anybody. I wouldn't even talk to any of the friends that l'd made. (Chelsea, female, 17 years, white, overweight) ${ }^{\text {w12s }}$

When I cry I eat, but then I eat because I'm crying, but I'm crying because I'm getting bigger, and it's just a vicious circle. (Vicki, female, 18 years, white, overweight) ${ }^{\text {w12i }}$ 
Table 2 Continued

\begin{tabular}{|c|c|}
\hline Themes & Illustrative quotes from participants (also see quotes in the text) (Study reference no.) \\
\hline \multicolumn{2}{|c|}{ Make sure, even when it's hard, you've got people there } \\
\hline $\begin{array}{l}\text { Easier said than done } \\
(w 13, p .5)\end{array}$ & $\begin{array}{l}\text { I've got a younger brother and we've got all these sort of stuff in house for him and then that's } \\
\text { just like a bit, a bit of a temptation... And sometimes when he gets right nice stuff and I'm sat } \\
\text { there eating, I don't know, fish, chips, and mushy peas and it's just not right. (Reg, female, } \\
13 \text { years, white, overweight) }{ }^{\text {w12l }} \\
\text { [after an exercise intervention] I felt healthier and better and stuff and I felt like I had actually } \\
\text { carried out something. Rather than going home and being a couch potato. (Male, } 15 \text { years, } \\
\text { white, very overweight, BMI } 37.6 \text { ) (w5, p.814) }\end{array}$ \\
\hline Yo-yos and pick me ups & $\begin{array}{l}\text { I was 14-years-old and having so much like, being so unhappy being overweight, finally getting } \\
\text { the weight off is amazing, then piling it all straight back on was just absolutely heartbreaking. } \\
\text { Yo-yoing up and down in normal diets just, has just become a way of life really now.... It just } \\
\text { makes you really doubt yourself. (Vicki, female, } 18 \text { years, white, overweight)w12e } \\
\text { [commenting on experience of a community-based weight-loss intervention] You have people } \\
\text { who are in the same situation as you... who know what it's like and things like that. If you have a } \\
\text { problem or if you have like just a total collapse... you've got people who will just pick you back } \\
\text { up. And I think that's been the most thing about it, the most important thing that l've had for me. } \\
\text { (Emily, female, } 14 \text { years, white, overweight) }{ }^{\text {w12l }}\end{array}$ \\
\hline $\begin{array}{l}\text { Be nice. You've got to } \\
\text { help }\end{array}$ & $\begin{array}{l}\text { There's ways to be more tactful. As you know, the doctors that l've had haven't always been } \\
\text { particularly nice about it... yeah, there's ways to say things nicely, and although sometimes you } \\
\text { need to go for the approach that says, 'You need to do something about your weight now, ' } \\
\text { there's, there's ways to be nice about it. (Holly, female, } 18 \text { years, white, very overweight) }{ }^{\text {w12p }} \\
\text { l'd just say to like parents that ... without you, you won't be, your child won't be able to do it. And } \\
\text { you've got to help them as much as they're helping themselves. And just, if you don't help them, } \\
\text { they'll think, 'Well, nobody's bothered, and, I do try but nobody sees difference.' (Alex, female, } \\
14 \text { years, ethnicity unspecified, overweight) } \\
\text { Make sure that even when it is hard, you've got people there. (Cris, } 14 \text { years, gender, ethnicity } \\
\text { and body size unspecified) (w13, p.4) }\end{array}$ \\
\hline
\end{tabular}

It's on your conscience all the time

This first main theme included ideas about what can influence body size, who is accountable and concerned, implications, and ideal, aspired to and acceptable bodies.

\section{It's down to me}

Some young people's accounts of what could influence their weight referred to relatively unchangeable physical phenomena, such as body metabolism, bone structure, puberty or genetics. ${ }^{\mathrm{w} 1}$ w7 w12 w28-w29 Young people of all sizes, however, emphasised the individual behaviours of being physically active and watching what you eat, ${ }^{\mathrm{w} 5-\mathrm{w} 7}$, w11 w12 w20 w23-w24 w27 w28 and considered body size was within their own control. ${ }^{\text {w11 w12 w28 }}$

One study reported that participants stated 'quite fervently' that a young person's size was their own responsibility $^{\text {w28 }}$ and in only two studies did young people suggest that some responsibility might lie elsewhere. ${ }^{\text {w12 }}{ }^{19}$ Young people who felt, or already were large made it clear that they knew they had to do something and tended to be critical of their own self-will.

\section{It's like a girl thing?}

Young people tended to identify young women as being more interested in body weight. ${ }^{\text {t7 }}$ w8 w10 w11 w12b w15 w19 ${ }^{\text {w29 }}$ As one put it, 'It's like a girl thing. It's like "oh she is wearing some tight jeans she looks awful"' (male, 13 years, ethnicity and body size unspecified) (w15, p.895). But accounts also identified young men's concerns, which had the additional focus of height and musculature. $^{\text {w2 w7 w11 w17 }}$

\section{If you're fat, then they don't like you}

Young people did not necessarily equate a large body size with ill health, ${ }^{\text {w28 }}{ }^{\text {w29 }}$ although the need to lose weight for their future health was identified by young people with a high weight. ${ }^{\text {w12k }}$ In one study framed explicitly around body size, only a minority spontaneously mentioned improved health as a benefit of losing weight. $^{\text {w28 }}$ Some (mainly young men) did report concern that an increased size might, or already was, reducing physical ability or performance. ${ }^{\text {w16 }}$

Far more emphasis was placed on the impact of body size on relationships. Young people with a healthy size identified how overweight young people would not be respected, ${ }^{\text {w18 }}$ or would be picked on, ${ }^{\mathrm{w} 7}$ or bullied ${ }^{\mathrm{w} 28}$ (See 'Day after day...' below). Relations with the opposite sex were particularly pertinent. ${ }^{\text {w8 }}$ w11 w12j w25 w30

\section{People that are right big have right dirty houses}

Young people, many who were themselves a large size, attributed a consistently similar set of negative characteristics to people with large bodies, describing them as 
lazy, or unable to control their desire for food, or both. $^{\text {w5 }}$ w17 w29 While sometimes young people made efforts not to appear judgemental of people with large bodies, this was not always the case. This, and participants' emphasis on individual control are illustrated by one young women saying, 'Fat people, I hate fat people. I don't hate their personalities, I just don't like the way they look. I just don't know why folk would do that to themselves.' (Elspeth, female, 13-15 years, white Scottish, body size unspecified) (w29, p.7).

\section{Being fat is really a bad thing}

Young people's ideas about which body sizes were valued were consistent across studies. Both sexes characterised an ideal young woman's body as thin, ${ }^{\text {12o w24 w30 }}{ }^{\text {slim, }}{ }^{\text {w17 }}$ or skinny. ${ }^{\text {22010v w22 }}$ For both sexes, the ideal for young men was muscular, ${ }^{\text {w2 }}$ w11 w15 w17 and looking fit. ${ }^{\text {w11 w17 }}$ Young men themselves added not too muscular ${ }^{\text {w8 }}$ w11 w12b and toned. ${ }^{\mathrm{w} 12 \mathrm{~b}}$ The aspirations of young people with healthy size bodies tended to refer to these ideals, or avoiding being very large.

In terms of unacceptable body sizes, over half the participants in one study of young women identified weight as the deciding factor for judging whether your appearance was acceptable or not (w7, p.148). A participant in another study was more specific, saying, 'Being fat is really a bad thing, more than anything. More than having a face that is not so good looking' (14-17 years, gender, ethnicity and body size unspecified) (w23, p.156).

Overweight young people expressed more complex views about size and acceptability, ${ }^{\mathrm{w} 12}$ w28 for example, explaining how valuing yourself was key to being found attractive by others.

\section{If I had the choice, I wouldn't be this size}

This second main theme incorporated the views of young people who would be, or had been, classified as overweight about their experience of being that size. For views on attempting to lose weight or maintain weight-loss, see 'Make sure, even when it's hard, you've got people there', below.

\section{Not wanting to stick out}

Overweight young people described how everyday social activities could be difficult because of their size. ${ }^{\text {w4 }}$ w9 w12 w28 Shopping trips and other social events could leave them feeling excluded, marked out as different and ashamed and could lead to them questioning themselves, ${ }^{\text {w12d w28 }}$ and spending a great deal of time on their own at home. ${ }^{\mathrm{w} 4}$ One participant described this sense of feeling different, saying 'I ... just wanted to be part of the crowd and not to stick out like a sore thumb... Because sticking out... when someone sees the person who looks, who is bigger than... most of them, almost everyone there, that makes you feel really bad' (Huw, male, 17 years, white, overweight). ${ }^{\mathrm{w} 12 \mathrm{~b}}$
Interacting even with friends could be difficult. Some larger young people reported friends saying that they were ashamed to be seen with them, ${ }^{\text {w12 }}$ others described feeling more confident with peers who knew them before they became overweight. ${ }^{\text {w9 }}$ p.S42 In addition to explicit cases of ridicule and abuse (see 'Day after day, you're that terrified'), young people described difficult conversations where their peers, who they judged not to be overweight, had described themselves as fat, solely to gain reassurance that they were not. ${ }^{\text {w4 w12 w17 w28 }}$

\section{Day after day, you're that terrified}

In just over a third of studies, young people of varied sizes identified bullying as something that was experienced when you had a large body size. ${ }^{\text {w2-w5 }}$ w9 w11-w15 w24 w28 Young people classified as very overweight reported severe incidents of physical abuse, that included being threatened with a knife, beaten, kicked, pushed down stairs and having objects thrown at them. ${ }^{\text {w4 w9 w12s }}$ Verbal abuse, such as name-calling and using slurs, was described as more common, but, along with less direct abuse, such as deliberate and extended isolation, whispering or sniggering, was the source of considerable distress. ${ }^{\mathrm{w} 4} \mathrm{w} 9 \mathrm{w} 12 \mathrm{c}$

School was the setting for much of the abuse and it had become so serious for some that they were unable to attend. Young people identified PE lessons as a particular source of exposure to humiliating ridicule. ${ }^{\text {w3 }}$ w9

Size-related abuse was heavily implicated by young people as a negative factor for their emotional health, leading to reduced confidence, anxiety (especially around venturing into public spaces), loneliness and depression. $^{\text {w9 w12c }}$

\section{Vicious circles}

Young people who would be classified as overweight described a variety of coping strategies. These included extreme withdrawal, as well as eating to reduce boredom, when stuck at home, and for comfort following bullying. ${ }^{\text {w12 }}$ Some described how these responses could leave them feeling worse and lead to other, additional difficulties, including further weight gain.

In contrast, others appeared to have developed more defiant coping strategies, as illustrated by one participant, who said, 'I know more fat jokes than anybody else going. I'm better at it than they are.... I got so low on so many occasions. Now it's just like 'you have a problem with me, that's your problem " (Ann, female, 17 years, ethnicity unspecified, overweight, BMI 43.3). ${ }^{\text {w9, p.S42 }}$

\section{Make sure, even when it's hard, you've got people there}

This third, and last, main theme incorporated the views of young people about what happens when they are overweight and try to lose weight. Also presented here are young people's suggestions as to what actions should be taken to support them in maintaining or reaching a healthy weight, and coping with related stresses and anxieties. 


\section{Easier said than done}

Larger young people described difficulties modifying what they ate, ${ }^{\mathrm{w} 12-\mathrm{w} 14}$ and frustration at repeated weight-loss attempts. ${ }^{\text {w12 }}$ They were sensitive to the additional effort they felt they had to put into regulating their food intake compared to their peers. ${ }^{\text {w12-w13 w24 As }}$ one participant in a residential camp put it, 'I thought 'I've been good now surely I can't spend the rest of my life spending as much focus on my weight as I have been doing'... people manage to stay the same weight and they don't really focus on it. They have their food... and they live their life' (Ashley, male, 16 years, ethnicity unspecified, very overweight) (w13, p.310).

These young people described various barriers to physical activity. In addition to the abuse described above when exercising in school, some said that getting tired, or out of breath too quickly, or other size-related physical complications, such as asthma, got in the way of their exercising. ${ }^{\mathrm{w} 5}$ w12 The availability of calorie-dense foods sometimes made it difficult to stick to healthy eating plans, especially when others were enjoying different kinds of food. ${ }^{\text {w12 }}$ w14 Others reported difficulties with family and friends' own size-related beliefs. These included incorrect dietary advice, ${ }^{\text {w12-w13 }}$ and unhelpful pressure to take, or not to take action. ${ }^{\mathrm{w} 12-\mathrm{w} 13 \mathrm{w} 28}$

Again emphasising personal responsibility, young people who had taken action successfully over their size emphasised the central importance of avoiding laziness, ${ }^{\mathrm{w} 5} \mathrm{w} 12 \mathrm{w} 28$ and being proud about taking action. ${ }^{\text {w12 }}$ w13 w21 w28

\section{Yo-yos and pick me ups}

Larger young people described frustration at the slow rate of substantial weight loss. ${ }^{\text {w12 }}$ They were preoccupied with the idea of weight rebounding. ${ }^{\text {w13 }}$ w14 w28 and described being demoralised by regaining weight. ${ }^{\text {w12 }}$ w13 When talking about things that were helpful for coping with this long-term process of weight loss, young people identified goals, and feedback from others in particular. ${ }^{\text {w12, w21 }}$ Also helpful was support from, and giving support to, others who were going through or had gone through, the same experience.

\section{Be nice. You've got to help.}

Overweight young people tended to suggest things that they themselves could or should do to support themselves. Some stated that education regarding the benefits of healthy eating and exercise was important. ${ }^{\text {w12 }}$ They also encouraged other overweight young people to access their psychological resources. ${ }^{\text {w12 }}$ w22 When it came to their suggestions as to what others could do, these centred around the need for professionals and other people to be less judgemental.

They suggested that families could support and encourage them by joining in with their attempts to pursue a healthy lifestyle. Above all, these young people repeatedly emphasised the need for support.

\section{DISCUSSION}

This is the first systematic review of which we are aware that attempts to configure perspectives about obesity from young people with a range of body sizes. It finds that young people in the UK emphasise the social implications of having a large body size more than they do the consequences for health, an overweight body size being problematic for relations with the opposite sex, and, as in our review of children's views, ${ }^{27}$ linked to having fewer friends in general and to being teased or bullied. This limited salience of the physical health outcomes of health behaviours has been found in previous reviews of other health-related topics. ${ }^{73}$ Similarly, the moralistic attitudes towards obesity and the negative stereotyping of people with larger bodies expressed by young people of all body sizes in this review have both been reported in studies of young people from other countries. ${ }^{74}$

However, the reports of the young people in the current review not only emphasise social consequences, they also refer to key social influences in young people's day-to-day environments that relate to body size. These young people identify ways in which people who are overweight, and ultimately weight itself, can be affected by the attitudes and behaviours of those around them. The overweight young people in the current review describe in some detail how weight-related taunting and abuse, and being marked out as unacceptably different, can lead to them feeling ashamed, isolated and fearful. Studies from outside the UK have found that overweight and obesity serve as a gateway to mental and emotional health problems in young people, engendering low selfesteem, depression, anxiety and poor body image. ${ }^{5}$ 74-78 Some young people also gave personal accounts of vicious cycles of bullying or isolation leading to comfort eating and lowered mood, weight gain and further bullying or isolation. Weight-based teasing has also been associated with maladaptive eating and weight control behaviours, such as binge eating in studies of US adolescents. ${ }^{79} 80$

Despite these accounts of social environments that are far from conducive to losing or maintaining weight, the young people in this review placed an overwhelming emphasis, regardless of their size, on personal responsibility in achieving and maintaining healthy weight. Far from abandoning this responsibility, young people of a high weight appeared all too aware of their perceived inadequacies. They described repeated failed attempts to maintain weight loss and blamed and doubted themselves when unsuccessful. When weight loss was successful, they were often proud at having conquered 'laziness'.

Confidence in this review's findings is bolstered by its comprehensive searches. Very sensitive searches of bibliographic databases were supplemented by other methods to seek out less easily found literature, including unpublished reports. As a result, the review also benefited from access to one study's excerpts from its 
interview transcripts (published online as part of a selfhelp website). ${ }^{4981}$ We were able to access some of this study's 'raw' data directly in some context as interviewer questions and the responses to these were presented together and often in sequence. The sample of this same study, which had a preponderance of overweight young people, along with the sampling approach of six other studies gives this review a good basis from which to study the views of overweight young people, in particular. The consultation with young people about the review's findings adds confidence that the main themes are ones that would be recognised by young people.

A limitation of the review was that it identified only a small body of studies that could be characterised as being research 'for' young people, rather than 'of' them. ${ }^{82}$ Only one study, for example, appears directly to have asked young people what they thought should be carried out to support them in developing or maintaining a healthy body size. There is a clear need for research to engage young people more actively in exploring the circumstances surrounding obesity. The time that has elapsed between the searches run in 2010 to identify studies for this review and the production of this paper might also mean that further includable studies now exist. We consider, however, that the daily lived experiences of young people with respect to obesity are unlikely to have changed significantly in the UK over this time. New studies might be able to contribute further detail or explanations to our review's synthesis, but would be unlikely to change the main, relatively abstract, themes that we have identified.

The young people in this review help remind us that approaches that merely educate and admonish individuals about lifestyles and being overweight are not only insufficient but also potentially counter-productive. Increasingly, practitioners at the front-line of care, along with members of the general public, researchers and policy-makers are signing up to coalitions that advocate for the inclusion in policy discussions of the perspectives of people who are very overweight. ${ }^{83} 84$ This systematic review can contribute to such debates in the UK, in that the views synthesised include clear demands that larger young people be encouraged, supported and freed from persecution so that they can deal with the complex phenomenon of obesity in ways that are most appropriate for them.

Contributors All authors contributed to the review protocol, as did Claire Stansfield (CS) and Josephine Kavanagh (both from the EPPI-Centre). All authors also contributed to the writing of this paper. JC, KD, RWR, CS and CV conducted searches, and JC, KD, RWR and CV screened studies, developed the data extraction tool, and described, appraised and synthesised studies. The NCB PEAR group, facilitated by Louca-Mai Brady and Deepa Pagarani, commented on interim findings.

Funding The study was funded by the Department of Health (England). Competing interests None.

Provenance and peer review Not commissioned; externally peer reviewed.

Disclaimer This is an independent report commissioned and funded by the Policy Research Programme in the Department of Health. The views expressed are not necessarily those of the Department.
Data sharing statement The full technical report of this systematic review is available at: http://eppi.ioe.ac.uk/cms/Default.aspx?tabid=3395. For the review's protocol see online supplementary file 5 .

Open Access This is an Open Access article distributed in accordance with the Creative Commons Attribution Non Commercial (CC BY-NC 3.0) license, which permits others to distribute, remix, adapt, build upon this work noncommercially, and license their derivative works on different terms, provided the original work is properly cited and the use is non-commercial. See: http:// creativecommons.org/licenses/by-nc/3.0/

\section{REFERENCES}

1. Health and Social Care Information Centre. Statistics on obesity, physical activity and diet: England, 2013. London: Health and Social Care Information Centre, 2013. http://www.hscic.gov.uk/catalogue/ PUB10364 (accessed Oct 2013).

2. Wake M, Canterford L, Patton GC, et al. Comorbidities of overweight/obesity experienced in adolescence: longitudinal study. Arch Dis Child 2010;95:162-8.

3. Wijga A, Scholtens S, Bemelmans W, et al. Comorbidities of obesity in school children: a cross-sectional study in the PIAMA birth cohort. BMC Public Health 2010;10:184.

4. Singh AS, Mulder C, Twisk JWR, et al. Tracking of childhood overweight into adulthood: a systematic review of the literature. Obes Rev 2008:9:474-88.

5. Zametkin A, Zoon $\mathrm{C}$, Klein $\mathrm{H}$, et al. Psychiatric aspects of child and adolescent obesity: a review of the past 10 years. J Am Acad Child Adolesc Psychiatry 2004;43:134-50.

6. Vandenbroeck IP, Goossens J, Clemens M. Building the obesity system map. Foresight tackling obesities: future choices. London: Department of Innovation, Universities and Skills, 2007. http://www. bis.gov.uk/assets/foresight/docs/obesity/12.pdf (accessed Oct 2013).

7. Hilton S, Patterson C, Teyhan A. Escalating coverage of obesity in UK newspapers: the evolution and framing of the 'Obesity Epidemic' from 1996 to 2010. Obesityi 2012;20:1688-95.

8. Saguy A, Riley K. Weighing both sides: morality, mortality, and framing contests over obesity. J Health Polit Policy Law 2005;30:869-923.

9. Butland B, Jebb S, Kopelman P, et al. Tackling obesity: future choices-project report. London: Department of Innovation Universities and Skills, 2007.

10. Swinburn B, Figger G, Raza F. Dissecting obesogenic environments: the development and application of a framework for identifying and prioritizing environmental interventions for obesity. Prev Med 1999;29:563-70.

11. Swinburn B, Egger $\mathrm{G}$. The runaway weight gain train: too many accelerators, not enough brakes. BMJ 2004;329:736-9.

12. Lobstein T, Baur L, Uauy R. Obesity in children and young people: a crisis in public health. Obes Rev 2004;5(Suppl 1):4-104.

13. Brewis A, Wutich A, Faletta-Cowden A, et al. Body norms and fat stigma in a global perspective. Curr Anthropol 2011;52:269-76.

14. Puhl RM, Heuer CA. The stigma of obesity: a review and update. Obesity 2009;17:941-64.

15. Sikorski C, Luppa M, Kaiser M, et al. The stigma of obesity in the general public and its implications for public health-a systematic review. BMC Public Health 2011;11:661.

16. Lewis S, Thomas SL, Hyde J, et al. 'I don't eat a hamburger and large chips every day!' A qualitative study of the impact of public health messages about obesity on obese adults. BMC Public Health 2010;10:309.

17. Puhl RM, Andreyeva T, Brownell KD. Perceptions of weight discrimination: prevalence and comparison to race and gender discrimination in America. Int J Obes 2008;32:992-1000.

18. Lewis S, Thomas SL, Blood RW, et al. How do obese individual perceive and respond to the different types of obesity stigma that they encounter in their daily lives? A qualitative study. Soc Sci Med 2011;73:1349-56

19. Oude Luttikhuis $\mathrm{H}$, Baur $\mathrm{L}$, Jansen $\mathrm{H}$, et al. Interventions for treating obesity in children. Cochrane Database Syst Rev 2009;1:CD001872.

20. Summerbell CD, Waters E, Edmunds LD, et al. Interventions for preventing obesity in children. Cochrane Database Syst Rev 2005;3: CD001871.

21. Oliver S, Kavanagh J, Caird J, et al. Health promotion, inequalities and young people's health: a systematic review of research. London EPPI-Centre, Social Science Research Unit, Institute of Education, University of London, 2008

22. Brannen J, Dodd K, Oakley A, et al. Young people, health and family life. Buckingham: Open University Press, 1994. 
23. Moore $\mathrm{H}$, Kindness $\mathrm{L}$. Establishing a research agenda for the health and wellbeing of children and young people in the context of health promotion. In: Moore HE. ed. Promoting the health of children and young people: setting a research agenda. London: Health Education Authority, 1998

24. Gough D, Oliver S, Thomas J. An introduction to systematic reviews. London: Sage, 2012.

25. Harden A, Garcia J, Oliver S, et al. Applying systematic review methods to studies of people's views: an example from public health. J Epidemiol Community Health 2004;58:794-800.

26. Rees R, Oliver S. Stakeholder perspectives and participation in reviews. In: Gough D, Oliver S, Thomas J. eds. An introduction to systematic reviews. London: Sage, 2012:17-34.

27. Rees R, Oliver K, Woodman J, et al. The views of young children in the UK about obesity, body size, shape and weight: a systematic review. BMC Public Health 2011;11:188

28. Lachal J, Orri M, Speranza M, et al. Qualitative studies among obese children and adolescents: a systematic review of the literature. Obes Rev 2013;14:351-68.

29. Lucas J, Arai L, Baird J, et al. A systematic review of lay views about infant size and growth. Arch Dis Child 2007;92:120-7.

30. Pocock M, Trivedi D, Wills W, et al. Parental perceptions regarding healthy behaviours for preventing overweight and obesity in young children: a systematic review of qualitative studies. Obes Rev 2010;11:338-53.

31. Ward CL. Parental perceptions of childhood overweight in the Mexican American population: an integrative review. J Sch Nurs 2008:24:407-16.

32. Thomas J, Brunton J, Graziosi S. EPPI-Reviewer 4.0: software for research synthesis. EPPI-Centre software. London: Social Science Research Unit, Institute of Education, University of London, 2010.

33. Peersman G, Oliver S. EPPI-Centre keywording strategy: data collection for the BiblioMap database. London: EPPI-Centre, Social Science Research Unit, Institute of Education, University of London, 1997.

34. Shepherd J, Kavanagh J, Picot J, et al. The effectiveness and cost-effectiveness of behavioural interventions for the prevention of sexually transmitted infections in young people aged 13 to 19: a systematic review and economic evaluation. Health Technol Assess 2010;14:1-206.

35. Harden A. 'Qualitative research', systematic reviews and evidence-informed policy and practice [Unpublished doctoral thesis] London: Institute of Education, 2007.

36. Thomas J, Harden A. Methods for the thematic synthesis of qualitative research in systematic reviews. BMC Med Res Methodol 2008;8:45.

37. PEAR. Public health, education, awareness, research. Our voices, our health: involving young people in public health research [Online] London: NCB, 2009. http://www.ncb.org.uk/PEAR (accessed Oct 2012).

38. Billings J, Hashem F, Macvarish J. Am I Bovvered? A participative action research study to develop, implement and evaluate physical activity interventions with girls: Phase One Report. Canterbury: University of Kent, Centre for Health Service Studies, 2008. http:// www.kent.ac.uk/chss/docs/Am I Bovvered_Phase_One.pdf (accessed Oct 2013).

39. Bramham P. Boys, masculinities and PE. Sport Educ Soc 2003;8:57-71.

40. Cockburn C, Clarke G. "Everybody's looking at you!": girls negotiating the "femininity deficit" they incur in physical education. Womens Stud Int Forum 2002;25:651-5.

41. Curtis P. The experiences of young people with obesity in secondary school: some implications for the healthy school agenda. Health Soc Care Community 2008;16:410-18.

42. Daley AJ, Copeland RJ, Wright NP, et al. 'I can actually exercise if I want to; it isn't as hard as I thought': a qualitative study of the experiences and views of obese adolescents participating in an exercise therapy intervention. J Health Psych 2008;13:810-19.

43. Flintoff A, Scraton S. Stepping into active leisure? Young women's perceptions of active lifestyles and their experiences of school physical education. Sport Educ Soc 2001;6:5-21.

44. Frost L. Young women's experience of body-hatred: stigma and shame. In: Frost L. ed. Young women and the body. A feminist sociology. Basingstoke: Palgrave, 2001:131-68.

45. Gorely T, Holroyd R, Kirk D. Muscularity, the habitus and the social construction of gender: towards a gender-relevant physical education. Br J Sociol Educ 2003;24:429-48.

46. Griffiths LJ, Page AS. The impact of weight-related victimization on peer relationships: the female adolescent perspective. Obesity 2008;16(Suppl 2):S39-45.
47. Grogan S, Fry G, Gough B, et al. Smoking to stay thin or giving up to save face? Young men and women talk about appearance concerns and smoking. Br J Health Psychol 2009;14:175-86.

48. Grogan S, Richards H. Body image: focus groups with boys and men. Men Masculinities 2002;4:219-32.

49. Health Experiences Research Group. Youthhealthtalk health and weight: topics. Oxford: Health Experiences Research Group, 2010 http://www.youthhealthtalk.org/young_people_health_and_weight/ (accessed Oct 2013)

50. Hester JR, McKenna J, Gately PJ. Obese young people's accounts of intervention impact. Patient Educ Couns 2009;79:306-14.

51. Holt NL, Bewick BM, Gately PJ. Children's perceptions of attending a residential weight-loss camp in the UK. Child Care Health Dev 2005;31:223-31.

52. Krayer A, Ingledew DK, Iphofen R. Social comparison and body image in adolescence: a grounded theory approach. Health Educ Res 2008;23:892-903.

53. Kurtz Z, Thornes R. The health needs of school age of children: the views of children, parents and teachers linked to local and national information. 2000. http://collection.europarchive.org/tna/ 20060802112753/http://www.wiredforhealth.gov.uk/PDF/ kurtzmarch00.pdf (accessed Oct 2013).

54. Lloyd B, Dittmar H. Girls' and boys' body image concerns [computer file]. Colchester, Essex: UK Data Archive [distributor], 19972000. SN: 4073. 1997. UKDA study number:4073.

54a. Lucas K, Lloyd B. Adolescent smoking: the control of mood and body image concerns. Health Education 1999;1:17-26.

55. Ludvigsen A, Sharma N. Burger boy and sporty girl: children and young people's attitudes towards food in school. Barkingside: Barnardo's, 2004

56. Mulvihill C, Rivers K, Aggleton P. Views of young people towards physical activity: determinants and barriers to involvement. Health Educ 2000;100:190-9.

57. Owen SE, Sharp DJ, Shield JP, et al. Childrens' and parents' views and experiences of attending a childhood obesity clinic: a qualitative study. Primary Health Care 2009;10:236-44.

58. Percy-Smith B. You think you know?...You have no idea: youth participation in health policy development. Health Educ Res 2007:22:879-94.

59. Reid M, Hendry LB. Illness anxiety and somatic health concerns of northern rural Scottish young people: implications for health care providers and educators. Health Educ J 2001;60:147-63.

60. Shucksmith J, Hendry L. Health issues and adolescents: growing up, speaking out. London: Routledge, 1998.

61. Velija P, Kumar G. GCSE physical education and the embodiment of gender. Sport Educ Soc 2009;14:383-99.

62. Wallace ML, Harcourt D, Rumsey N, et al. Managing appearance changes resulting from cancer treatment: resilience in adolescent females. Psychooncology 2007;16:1019-27.

63. Willett R. 'What You Wear Tells a Lot about You:' girls dress up online. Gender Educ 2008;20:421-34.

64. Wills W, Backett-Milburn K, Gregory S, et al. Young teenagers' perceptions of their own and others' bodies: a qualitative study of obese, overweight and 'normal' weight young people in Scotland. Soc Sci Med 2006;62:396-406.

65. Wills W, Backett-Milburn K, Lawton J, et al. Parents' and teenagers' conceptions of diet, weight and health: does class matter? Full research report. Swindon: ESRC, 2008.

66. Wills WJ. Food and eating practices during the transition from secondary school to new social contexts. J Youth Stud 2005;8:97-110.

67. Bhugra D, Bhui K. Eating disorders in teenagers in East London: a survey. Eur Eat Disord Rev 2003;11:46-57.

68. Inchley J, Kirby J, Currie C. Physical Activity in Scottish Schoolchildren (PASS) project: physical activity among adolescents in Scotland: final report of the PASS study. Edinburgh: Child and Adolescent Health Research Unit, The University of Edinburgh, 2008.

69. Jackson A, Harris P. Tackling obesities: future choicesperspectives of 13-year-olds. London: Government Office for Science, 2007.

70. Kaplan-Myrth N. Alice without a looking glass: blind people and body image. Anthropol Med 2000;7:277-99.

71. McAlister S, Neill G. Young women's positive and negative perceptions of self in Northern Ireland. Child Care Pract 2007;13:167-84.

72. Reid M. Debrief of a study to identify and explore parental, young people's and health professionals' attitudes, awareness and knowledge of child healthy weight. Edinburgh: NHS Health Scotland, 2009. 
73. Shepherd J, Harden A, Rees R, et al. Young people and healthy eating: a systematic review of research on barriers and facilitators. Health Educ Res 2006;21:239-57.

74. Puhl R, Latner J. Stigma, obesity, and the health of the nation's children. Psychol Bull 2007;133:557-80.

75. Erermis $\mathrm{S}$, Cetin N, Tamar M, et al. Is obesity a risk factor for psychopathology among adolescents? Pediatr Int 2004;46:296-301.

76. Amaral O, Pereira $\mathrm{C}$, Veiga $\mathrm{N}$, et al. Obesity and depressive symptoms in adolescents. Am J Epidemiol 2006;163(11S):S219.

77. Sjoberg RL, Nilsson KW, Leppert J. Obesity, shame, and depression in school-aged children: a population-based study. Pediatrics 2005;116:e389.

78. Viner R, Haines M, Taylor S, et al. Body mass, weight control behaviours, weight perception and emotional well-being in a multiethnic sample of early adolescents. Int $J$ Obes 2006;30:1514-21.
79. Haines J, Neumark-Sztainer D. Prevention of obesity and eating disorders: a consideration of shared risk factors. Health Educ Res 2006;21:770-82.

80. Neumark-Sztainer D, Falkner N, Story M, et al. Weight-teasing among adolescents: correlations with weight status and disordered eating behaviors. Int J Obes 2002;26:123-31.

81. Ziebland S, McPherson A. Making sense of qualitative data analysis: an introduction with illustrations from DIPEx (personal experiences of health and illness). Med Educ 2006;40:405-14.

82. Hood S, Kelley P, Mayall B. Children as research subjects: a risky enterprise. Child Soc 1996;10:117-28.

83. Lobstein T, Brinsden $\mathrm{H}$, Landon J, et al. INFORMAS and advocacy for public health nutrition and obesity prevention. Obes Rev 2013;14: $150-6$

84. Swinburn B, Wood A. Progress on obesity prevention over 20-years in Australia and New Zealand. Obes Rev 2013;14:60-8. 